\title{
THE RELEASE OF ALUMINUM FROM ALUMINOSILICATE MINERALS. II. ACID-BASE POTENTIOMETRIC TITRATIONS
}

\author{
F. CABrera ${ }^{1}$ and $O$. Talibudeen \\ Soils and Plant Nutrition Department, Rothamsted Experimental Station \\ Harpenden, Hertfordshire, AL5 2JQ
}

(Received 5 May 1978)

\begin{abstract}
Acidified suspensions of Al-saturated kaolinite, montmorillonite, mica, illite, and biotite in $10^{-3}$ $\mathrm{M} \mathrm{NaNO}_{3}$ were potentiometrically titrated with $0.1 \mathrm{~N} \mathrm{NaOH}$ and $0.1 \mathrm{~N} \mathrm{HNO}_{3}$ in succession in a $\mathrm{CO}_{2}$-free nitrogen atmosphere. The resulting curves were compared with those for $\mathrm{Al}\left(\mathrm{NO}_{3}\right)_{3}$ solutions of similar $\mathrm{Al}$ concentration in the supernatant solution and corrected for $\mathrm{Al}$ in the entrained solution in the clay.

Base titrations of $\mathrm{Al}$ ions adsorbed on all the minerals, except montmorillonite, showed two $\mathrm{pH}$ inflections separated by a buffering range. With montmorillonite, there were three $\mathrm{pH}$ inflections similar to those for $\mathrm{Al}$ in solution. The first inflections in the titration of suspensions occurred at lower pHs and were less pronounced than for $\mathrm{Al}$ in solution. These represent the titration of $\mathrm{H}_{3} \mathrm{O}^{+}$sorbed during the pretreatment. The buffering by adsorbed $\mathrm{Al}$ ions is also less than that by $\mathrm{Al}$ in solution.

The $\mathrm{OH}^{-}$used up by adsorbed $\mathrm{Al}$ ions between the first and last inflections was equal to, or slightly greater than, the CEC of the minerals, except for mica where it was more than twice the CEC, because new interlayer surfaces were formed during the acid pretreatment. Acid titration curves of $\mathrm{Al}$ ions in the adsorbed and solution states showed hysteresis when related to the base titration curves. The use of two titration speeds ( 3 and $0.3 \mathrm{pH}$ units/hr) only slightly affected the titration curves of the minerals suggesting that the observed effects were not caused by lack of equilibrium with added base or acid.
\end{abstract}

Key Words-Aluminum, Biotite, Buffer, Illite, Kaolinite, Mica, Montmorillonite

\section{INTRODUCTION}

The existence of partially hydrolyzed $\mathrm{Al}$ ions on the surface of acid soils and clays was suggested by several authors from the study of the composition of the extracts with various salt solutions (Bache, 1974; Dalal, 1975; Bache and Sharp, 1976a, 1976b; Smith and Emerson, 1976; Cabrera and Talibudeen, 1978) from the composition of the solution in equilibrium with these materials (Chakravarti and Talibudeen, 1961) and from the adsorption of Al from solution (Brown and Newman, 1973).

Using potentiometric titration, Low (1955) determined the amount of $\mathrm{Al}^{3+}$ in a $\mathrm{H}$-Al-bentonite with different proportions of $\mathrm{H} / \mathrm{Al}$ on its surface. He found that the $\mathrm{pH}$ of $\mathrm{Al}(\mathrm{OH})_{3}$ precipitation in bentonite suspension was higher than in free solution and attributed this to the lower activity of $\mathrm{Al}$ ions in suspension because of electrostatic interaction with the clay. Schwertmann and Jackson $(1963,1964)$ found three buffer ranges in the $\mathrm{pH}$ titration curve of aged H-Wyoming bentonite and $\mathrm{H}$-vermiculite, and attributed these, in order of ascending $\mathrm{pH}$, to exchangeable $\mathrm{H}^{+}$, exchangeable $\mathrm{Al}^{3+}$, and basic Al compounds formed in the presence of these negatively charged clays. The third buffer range increased greatly on aging the $\mathrm{H}$-saturated clay and was comparable to the third buffering range observed in

\footnotetext{
${ }^{1}$ Permanent address: Centro de Edafologia y Biologia Aplicada del Cuarto (C.S.I.C.), Apartado 1052, Sevilla, Spain.
}

aged, partially neutralized $\mathrm{AlCl}_{3}$ solutions. Smith and Emerson (1976) observed that potentiometric titration curves of kaolinite were not helpful in trying to decide the forms of Al present although they showed that some of it was as $\mathrm{Al}^{3+}$. Pyman et al. (1976) reported that the apparent hydrolysis constants of Al calculated from base titration curves of Al-bentonite were smaller than those of the $\mathrm{Al}$ ions in solution.

The titration curves of $\mathrm{Al}$ in solution depend on $\mathrm{Al}$ concentration, ionic strength, temperature, titration speed, method of titrant injection, etc. (Frink and Sawhey, 1967; Vermeulen et al., 1975; Stol et al., 1976). From a theoretical treatment of the base titration of dilute $\mathrm{AlCl}_{3}$ solutions, Turner (1968a, 1968b) predicted different shapes of titration curves depending on the $\mathrm{Al}$ species assumed to be present in solution. It seems then that the kind of $\mathrm{Al}$ species formed in solution during titration depends very much on experimental conditions and that adsorbing surfaces in suspensions modify this.

The present paper examines titration curves of $\mathrm{Al}$ adsorbed on Al-saturated minerals and compares them with the titration curves of $\mathrm{Al}$ in solution under similar experimental conditions.

\section{MATERIALS AND METHODS}

\section{Minerals}

The relevant properties of the minerals used in this work are listed in Table 1; (for a fuller description, see Cabrera and Talibudeen, 1978). 
Table 1. Description of minerals.

\begin{tabular}{lcc}
\hline \multicolumn{1}{c}{ Mineral } & $\begin{array}{c}\text { Particle-size } \\
\mu \mathrm{m}\end{array}$ & $\begin{array}{c}\text { CEC } \\
\text { meq/1000 } \mathrm{g}\end{array}$ \\
\hline Kaolinite A (St. Austell) & $0.5-0.25$ & 76 \\
Kaolinite B (St. Austell) & $2.5-1.5$ & 32 \\
Montmorillonite (Upton) & $0.2-1$ & 733 \\
Mica (Muscovite) & $<1$ & 124 \\
Illite (Fithian No. 35) & $<1$ & 237 \\
Biotite (Ontario) & $<50$ & 47
\end{tabular}

Potentiometric titration of Al-saturated minerals and Al $\left(\mathrm{NO}_{3}\right)_{3}$ solutions

Weighed samples of mineral were treated with $10 \mathrm{ml}$ of $0.1 \mathrm{~N} \mathrm{Al}\left(\mathrm{NO}_{3}\right)_{3}$ solution adjusted to $\mathrm{pH} 3$ in polypropylene centrifuge tubes. After shaking overnight, the tubes were centrifuged and the supernatant solution rejected. This treatment was repeated three times to ensure that the concentration and $\mathrm{pH}$ of the final supernatant were those of the added solution. The Al-saturated minerals with entrained $\mathrm{Al}\left(\mathrm{NO}_{3}\right)_{3}$ solution were shaken intermittently for $1 \mathrm{hr}$ with $50 \mathrm{ml}$ of $10^{-3} \mathrm{M}$ $\mathrm{NaNO}_{3}$ and centrifuged. Twenty-five milliliters of the clear supernatant were taken out. The suspension and the supernatant ('control') each were mixed with $25 \mathrm{ml}$ of $10^{-3} \mathrm{M} \mathrm{NaNO}_{3}$ solution and saturated with $\mathrm{CO}_{2}$-free nitrogen for $1 \mathrm{hr}$, and $0.1 \mathrm{~N} \mathrm{HNO}_{3}$ was added slowly over ca. $24 \mathrm{hr}$ to bring the $\mathrm{pH}$ to approximately 2 . When the $\mathrm{pH}$ remained steady for $1 \mathrm{hr}$ after adding the acid, 'suspension' and 'control' were titrated to $\mathrm{pH} 11$ with $0.1 \mathrm{~N} \mathrm{NaOH}$ and then back to $\mathrm{pH} 2$ with $0.1 \mathrm{~N} \mathrm{HNO}_{3}$. $\mathrm{CO}_{2}$-free nitrogen gas was bubbled throughout to prevent $\mathrm{CO}_{2}$ absorption from the air. The temperature was kept constant at $25 \pm 2{ }^{\circ} \mathrm{C}$.

To help interpret the titration curves of the Al-saturated minerals, solutions of $\mathrm{Al}\left(\mathrm{NO}_{3}\right)_{3}$ containing 0.499 and $1.000 \mathrm{meq} \mathrm{Al}^{3+}$ in $50 \mathrm{ml}$ and $25 \mathrm{ml}$ of $10^{-3} \mathrm{M} \mathrm{NaNO}_{3}$ were also titrated after adding acid to bring the $\mathrm{pH}$ to approximately 2 . (The final concentrations of these solutions were then $2.9 \times 10^{-3} \mathrm{M}$ and $1.1 \times 10^{-2} \mathrm{M}$, respectively.)

The titrations were done on a Radiometer automatic titrator (model Copenhagen TTT2b) coupled to an Autoburette $\mathrm{ABU} 12 \mathrm{~b}$ and a Titrigraph SBR3. Mean speeds of $3 \mathrm{pH}$ units $/ \mathrm{hr}$ and $0.3 \mathrm{pH}$ units/hr were used on both acid and base titrations with standardized 0.1 $\mathrm{M} \mathrm{HNO}_{3}$ and $0.1 \mathrm{M} \mathrm{NaOH}$.

\section{RESULTS AND DISCUSSION}

Titration curves of $\mathrm{Al}\left(\mathrm{NO}_{3}\right)_{3}$ solutions

The base titration curves of acidified aluminum nitrate solutions (Figure 1) showed three inflection points separated by two plateaus whose exact locations were found by means of the differentiated curves. The first inflection point determines the neutralization equivalence of the excess $\mathrm{H}_{3} \mathrm{O}^{+}$initially present, the second

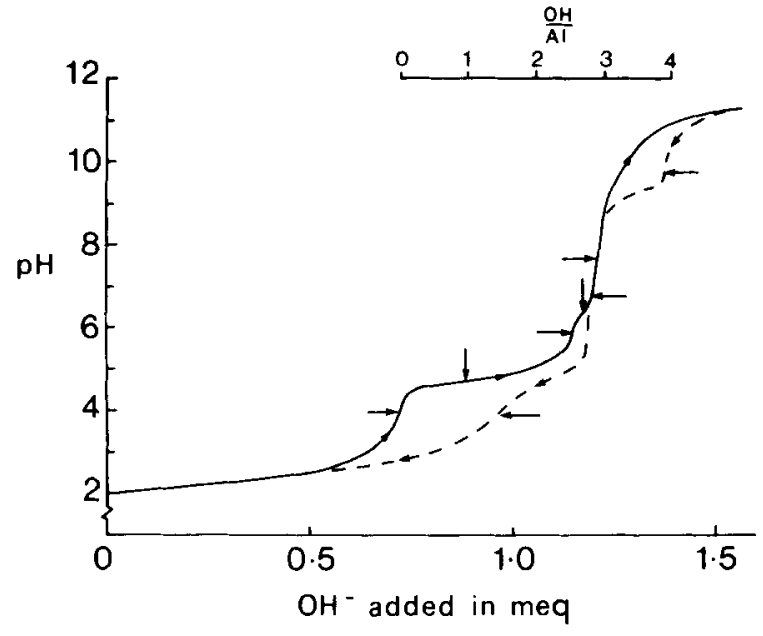

Figure 1. Base (-) and acid (-- - ) titration curves of acidified $2.9 \times 10^{-3} \mathrm{M} \mathrm{Al}\left(\mathrm{NO}_{3}\right)_{3}$ in $10^{-3} \mathrm{M} \mathrm{NaNO}_{3}$. Titration speed $0.3 \mathrm{pH}$ units $/ \mathrm{hr}$. Horizontal and vertical arrows mark inflection points and plateaus, respectively.

is associated with the formation of a solid phase, and the third determines the total neutralization of the Lewis acid $\mathrm{Al}^{3+}$ (see also Vermeulen et al., 1975). These titration characteristics changed only slightly with titration speed.

The total $\mathrm{Al}^{3+}$ titrated (i.e., the difference of $\mathrm{OH}^{-}$ used between the first and third inflections) was $3.5 \%$ less than the total $\mathrm{Al}^{3+}$ taken initially, which is attributed to experimental error. However, Vermeulen et al. (1975) found by microelectrophoretic measurement that the Al hydroxide particles formed during the titration are positively charged up to $\mathrm{pH} 10$, which suggests that the $\mathrm{Al}^{3+}$ ions may not have been fully titrated at $\mathrm{pH}$ 7.4 .

The OH/Al ratios calculated on the basis of the total $\mathrm{Al}$ in solution initially are given in Table 2 for the two Al concentrations (mean of two titration speeds) and in Figure 1 for the dilute solution at a titration speed of 0.3 $\mathrm{pH}$ units $/ \mathrm{hr}$. The $\mathrm{pH}$ values at the inflection points and the plateaus, and the $\mathrm{OH} / \mathrm{Al}$ ratios at each $\mathrm{pH}$ were smaller for the more concentrated Al solution (see also Stol et al., 1976). The second inflection and plateau became less pronounced and finally disappeared as the initial Al concentration was decreased below $5.7 \times$ $10^{-4} \mathrm{M}$. This was also reported by Frink and Sawhey (1967) for $10^{-4} \mathrm{M}$ solutions, and for $10^{-2} \mathrm{M}$ solutions at high titration speeds, and by Stol et al . (1976) for $5 \times 10^{-5}$ $\mathrm{M} \mathrm{Al}$ solution and for any Al concentration when alkali was added dropwise to the surface of the solution without continuous stirring, creating locally 'higher-thanmean' concentrations of $\mathrm{OH}$ ions. The occurrence of this second inflection and plateau was related to the existence of positively charged Al-hydroxy polymers in partially neutralized, concentrated Al solutions. 


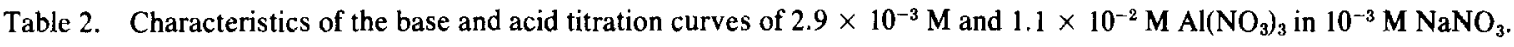

\begin{tabular}{|c|c|c|c|c|c|c|c|c|c|c|c|c|}
\hline & \multicolumn{6}{|c|}{$2.9 \times 10^{-3} \mathrm{M}$} & \multicolumn{6}{|c|}{$1.1 \times 10^{-2} \mathrm{M}$} \\
\hline & \multirow{2}{*}{ 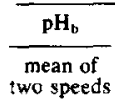 } & \multicolumn{2}{|c|}{$\mathrm{pH}_{\mathrm{a}}$} & \multirow{2}{*}{$\frac{(\mathrm{OH} / \mathrm{Al})_{\mathrm{b}}}{\begin{array}{c}\text { mean of } \\
\text { two speeds }\end{array}}$} & \multicolumn{2}{|c|}{$(\mathrm{OH} / \mathrm{Al})_{\mathrm{a}}$} & \multirow{2}{*}{ 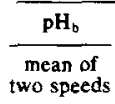 } & \multicolumn{2}{|c|}{$\mathrm{pH}_{\mathrm{B}}$} & \multirow{2}{*}{$\frac{(\mathrm{OH} / \mathrm{Al})_{\mathrm{b}}}{\begin{array}{c}\text { mean of } \\
\text { two speeds }\end{array}}$} & \multicolumn{2}{|c|}{$(\mathrm{OH} / \mathrm{Al})_{\mathrm{a}}$} \\
\hline & & $\begin{array}{c}\text { speed } \\
1\end{array}$ & ${ }_{2}^{\text {speed }}$ & & $\begin{array}{c}\text { speed } \\
1\end{array}$ & $\underset{2}{\text { speed }}$ & & $\begin{array}{c}\text { speed } \\
1\end{array}$ & $\begin{array}{c}\text { speed } \\
2\end{array}$ & & $\begin{array}{c}\text { speed } \\
1\end{array}$ & $\begin{array}{l}\text { speed } \\
2\end{array}$ \\
\hline lst inflection & 3.94 & 3.82 & 3.97 & 0 & 0.72 & 1.49 & 3.70 & 3.76 & 3.60 & 0 & 0.34 & 2.22 \\
\hline Ist plateau & 4.65 & - & - & 0.95 & - & - & 4.44 & - & - & 0.89 & - & - \\
\hline 2nd inflection & 5.85 & - & - & 2.16 & - & - & 5.50 & - & - & 2.49 & - & - \\
\hline 2nd plateau & 6.25 & - & - & 2.71 & - & - & 6.10 & 一 & - & 2.66 & - & - \\
\hline 3rd inflection & 7.44 & 6.78 & 6.70 & 2.92 & 2.90 & 2.80 & 7.30 & 7.85 & 6.67 & 2.87 & 3.04 & 2.91 \\
\hline 3rd plateau & - & - & - & - & - & - & - & - & - & - & - & - \\
\hline 4th inflection & - & 9.60 & 9.72 & - & 3.81 & 3.90 & - & 10.22 & 10.35 & - & 4.29 & 3.74 \\
\hline Standard Error & \pm 0.08 & - & - & \pm 0.03 & - & - & \pm 0.05 & - & - & \pm 0.02 & - & - \\
\hline
\end{tabular}

Note: Subscripts a and $b$ refer to the acid and base titrations, respectively.

The acid titration curves (Figure 1) showed hysteresis when related to the base titration curves, more so at the titration speed $0.3 \mathrm{pH}$ units/hr than at $3 \mathrm{pH}$ units/ hr (Table 2), presumably because the titration with $\mathrm{NaOH}$ at the slower speed caused larger and more crystalline nuclei of $\mathrm{Al}_{2} \mathrm{O}_{3} \cdot \mathrm{nH}_{2} \mathrm{O}$ to form which reacted more slowly during the reverse acid titrations. The second inflection in the base titration did not occur in the acid titration curve, and the first and third inflections occurred at slightly lower $\mathrm{pH}$ values (Figure 1 and Table 2). The amount of acid added between these inflections was less than expected from the total $\mathrm{Al}^{3+}$ in solution initially, more so at the slower titration speed. The inflection at about $\mathrm{pH} 4$ was less pronounced than in the base titration curve and at the end of the acid titration (i.e., $\mathrm{pH}$ 2), the solution was still slightly turbid. This suggests that the precipitate formed during the base titration had aged considerably, resisting subsequent dissolution during acid titration, and more so at the slower titration speed (see above).

In the acid titration curve, another inflection oc- curred between $\mathrm{pH} 9.5$ and 10.5 when the ratio $\mathrm{OH} / \mathrm{Al}$ was $<4$ (Figure 1 and Table 2); this did not appear in the base titration curves. This inflection is caused by the reaction of the aluminate ions, $\mathrm{AlO}_{2}{ }^{-}$, with $\mathrm{H}^{+}$to form $\mathrm{Al}_{2} \mathrm{O}_{3} \cdot \mathrm{nH}_{2} \mathrm{O}$. The theoretical $\mathrm{OH} / \mathrm{Al}$ ratio of 4 was not reached because, at the end of the base titration $(\mathrm{pH}$ 11), all the $\mathrm{Al}$ had not been converted to the $\mathrm{AlO}_{2}{ }^{-}$form, and the solution was still turbid.

\section{Titration curves of Al-saturated minerals}

The base titration curves of acidified suspensions of Al-saturated minerals showed, in general, two inflections separated by a plateau, except in montmorillonite which had three inflections and two plateaus resembling those of the concentrated Al solutions (Figure 2 and Table 3). The $\mathrm{pH}$ values at which inflections and plateaus occurred were the same, or only slightly different, using titration speeds of 3 and $0.3 \mathrm{pH}$ units/hr.

The inflections and plateaus can be attributed to the same causes as with the base titration curves of Al solutions (see previous section). The titration includes

Table 3. Characteristics of the base titration curve of acidified Al-saturated minerals in $10^{-3} \mathrm{M} \mathrm{NaNO}_{3}$.

\begin{tabular}{|c|c|c|c|c|c|c|c|}
\hline & & $\begin{array}{c}\text { Ist } \\
\text { inflection } \\
\text { pH }\end{array}$ & $\begin{array}{c}\text { 1st } \\
\text { plateaus } \\
\text { pH }\end{array}$ & $\begin{array}{l}\text { 2nd } \\
\text { infiection } \\
\text { pH }\end{array}$ & $\begin{array}{c}\text { 2nd } \\
\text { piateau } \\
\text { pH }\end{array}$ & $\begin{array}{c}\text { 3rd } \\
\text { infection } \\
\mathbf{p H}\end{array}$ & $\begin{array}{c}\text { meq } \mathrm{OH}^{-} \\
\text {consumed } \\
\text { per } 6000 \mathrm{~g} \text { of } \\
\text { mineral }\end{array}$ \\
\hline Kaolin A & $\left\{\begin{array}{l}\text { Fast } \\
\text { Slow }\end{array}\right.$ & $\begin{array}{l}3.75 \\
3.90\end{array}$ & $\begin{array}{l}4.37 \\
4.60\end{array}$ & - & - & $\begin{array}{l}7.30 \\
7.00\end{array}$ & $\begin{array}{l}79 \\
88\end{array}$ \\
\hline Kaolin B & $\left\{\begin{array}{l}\text { Fast } \\
\text { Slow }\end{array}\right.$ & $\begin{array}{l}3.95 \\
3.95\end{array}$ & $\begin{array}{l}4.50 \\
4.55\end{array}$ & - & - & $\begin{array}{l}7.25 \\
7.15\end{array}$ & $\begin{array}{l}40 \\
47\end{array}$ \\
\hline Montmorillonite & $\left\{\begin{array}{l}\text { Fast } \\
\text { Slow }\end{array}\right.$ & $\begin{array}{l}3.50 \\
3.50\end{array}$ & $\begin{array}{l}4.17 \\
4.17\end{array}$ & $\begin{array}{l}4.75 \\
4.70\end{array}$ & $\begin{array}{l}5.75 \\
5.70\end{array}$ & $\begin{array}{l}7.60 \\
7.25\end{array}$ & $\begin{array}{l}739 \\
728\end{array}$ \\
\hline Mica & $\left\{\begin{array}{l}\text { Fast } \\
\text { Slow }\end{array}\right.$ & $\begin{array}{l}3.37 \\
3.37\end{array}$ & $\begin{array}{l}4.50 \\
4.50\end{array}$ & - & - & $\begin{array}{l}6.00 \\
6.00\end{array}$ & $\begin{array}{l}393 \\
400\end{array}$ \\
\hline Illite & $\left\{\begin{array}{l}\text { Fast } \\
\text { Slow }\end{array}\right.$ & $\begin{array}{l}3.87 \\
3.87\end{array}$ & $\begin{array}{l}4.30 \\
4.37\end{array}$ & - & - & $\begin{array}{l}6.50 \\
6.50\end{array}$ & $\begin{array}{l}240 \\
242\end{array}$ \\
\hline Biotite & $\left\{\begin{array}{l}\text { Fast } \\
\text { Slow }\end{array}\right.$ & $\begin{array}{l}4.10 \\
5.45\end{array}$ & $\begin{array}{l}4.60 \\
6.60\end{array}$ & - & - & $\begin{array}{l}6.13 \\
7.31\end{array}$ & $\begin{array}{l}42 \\
36\end{array}$ \\
\hline
\end{tabular}

Fast $=3 \mathrm{pH}$ units $/ \mathrm{hr} ;$ Slow $=0.3 \mathrm{pH}$ units $/ \mathrm{hr}$. 


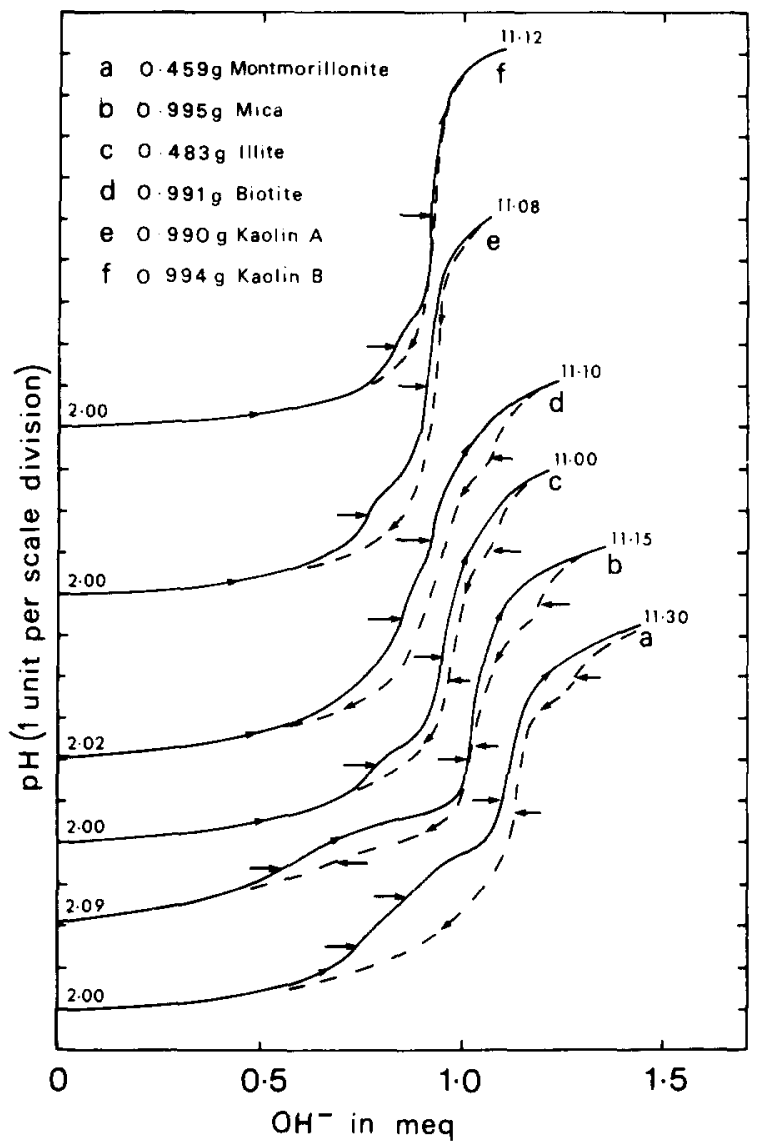

Figure 2. Base ( - ) and acid titration curves $(---)$ in $10^{-3}$ $\mathrm{M} \mathrm{NaNO}{ }_{3}$ of acidified $\mathrm{Al}$ saturated montmorillonite, mica, illite, biotite, kaolin A, and kaolin B. Titration speed is $0.3 \mathrm{pH}$ units $/ \mathrm{hr}$, except for biotite at $3 \mathrm{pH}$ units/hr. Initial and final $\mathrm{pH}$ values are indicated on the curves; horizontal arrows mark the inflection points.

adsorbed $\mathrm{Al}$ ions and the free $\mathrm{Al}$ in the entrained solution, estimated from the 'control.' The $\mathrm{OH}^{-}$used by the adsorbed $\mathrm{Al}$ ions was calculated by difference (Table 3).

The $\mathrm{OH}^{-}$used in titrating the adsorbed Al (Table 3) was almost equal to the CEC of most minerals (Table 1). The slight excess for kaolin, illite, and biotite is accounted for by the $\mathrm{pH}$-dependent negative charge developed from $\mathrm{pH} 6$ onwards. For mica, the $\mathrm{OH}^{-}$used was more than twice its CEC, presumably because of the dissolution of $\mathrm{Al}$ from the mineral matrix in the previous treatment with $0.1 \mathrm{M} \mathrm{HNO}_{3}$ to $\mathrm{pH} 2$ creating new interlayer surfaces, and subsequent base-titration of this Al (see also Cabrera and Talibudeen, 1978). This phenomenon may be the initial step in the formation of chloritized micas in soils (de Villiers and Jackson, 1967a, 1967b).

The first inflection in the base titration curves of the Al-saturated mineral suspensions (Figure 2) is less pro- nounced and occurs at lower $\mathrm{pH}$ values than in those for $\mathrm{Al}\left(\mathrm{NO}_{3}\right)_{3}$ solutions of similar $\mathrm{Al}$ concentration, except in biotite (cf. Tables 2 and 3). It would seem from this that adsorbed $\mathrm{Al}$ is more acidic than $\mathrm{Al}$ in solution, the opposite to what is expected because the activity of adsorbed $\mathrm{Al}$ ions is less than in free solution (Low, 1955). However, in the pretreatment with acid to bring the suspension to $\mathrm{pH} 2$, the ratio of sorbed $\mathrm{H}_{3} \mathrm{O}^{+}$to sorbed $\mathrm{Al}^{3+}$ ions is about $10: 1$, so it is more likely that the first inflection represents the $\mathrm{pH}$ at which mostly the sorbed $\mathrm{H}_{3} \mathrm{O}^{+}$is titrated. If so, the inflections corresponding to the titration of sorbed $\mathrm{H}_{3} \mathrm{O}^{+}$and $\mathrm{Al}^{3+}$ ions will be fully distinguishable only if the ratio of the equilibrium constants for the two reactions is $>10^{4}$ (Vogel, 1961) and measurable concentrations of both ionic species are present. Schwertmann and Jackson (1963, 1964) found that the first inflection shifts to higher $\mathrm{pH}$ values with increasing time of ageing of $\mathrm{H}$-bentonite and $\mathrm{H}$-vermiculite suspensions (i.e., with progressive changes from H-clay $\rightarrow \mathrm{H}$-Al-clay $\rightarrow$ Al-clay).

The plateaus in the base titration curves of Al-saturated minerals are less pronounced than those of the corresponding curves for $\mathrm{Al}$ in solution. In the latter, the existence of hydroxy Al polymers can be detected only by the shape of the curve (i.e., second inflection and plateau) above a limiting concentration of Al. Rich (1970) observed that the second inflection and plateau of the base titration curves of $\mathrm{Al}$ in solution disappeared when K-montmorillonite was added to the system. Therefore, little can be said, in a quantitative sense, about the nature of adsorbed $\mathrm{Al}$ ions from such potentiometric titration. However, the observation of the more complex buffering of adsorbed $\mathrm{Al}$ than of $\mathrm{Al}$ in solution points to its resistance to reaction with added $\mathrm{OH}^{-}$ions because of the strong binding of $\mathrm{Al}^{3+}$ and to the existence of hydroxy-polymeric Al (Cabrera and Talibudeen, 1978) on mineral surfaces, which therefore titrate at higher $\mathrm{pH}$ values.

The acid titration curves of the adsorbed $\mathrm{Al}$ (as with $\mathrm{Al}$ in solution) show hysteresis relative to the base titration curves and an extra inflection at $\mathrm{pH}$ 9-10. Changing the titration speed alters the curves only slightly, unlike the titration of $\mathrm{Al}$ in solution. The first and second inflections are difficult to distinguish from each other and the third inflection is observed at $\mathrm{pH}$ 6-7. However, no precise interpretation can be given for these inflections from this work.

\section{ACKNOWLEDGMENTS}

F. Cabrera thanks the Ramsay Memorial Fellowships Trust and the Consejo Superior de Investigaciones Cientificas (C.S.I.C.) for financial support.

\section{REFERENCES}

Bache, B. W. (1974) Soluble aluminium and calcium-aluminium exchange in relation to the $\mathrm{pH}$ of dilute calcium chloride suspensions of acid soils: J. Soil Sci. 25, 320-332. 
Bache, B. W. and Sharp, G. S. (1976a) Characterization of mobile aluminium in acid soils: Geoderma 15, 91-101.

Bache, B. W. and Sharp, G. S. (1976b) Soluble polymeric hydroxy-aluminium ions in acid soils: J. Soil Sci. 27, 167174.

Brown, G. and Newman, A. C. D. (1973) The reactions of soluble aluminium with montmorillonite: J. Soil Sci. 24, 337-354.

Cabrera, F. and Talibudeen, O. (1978) The release of aluminum from aluminosilicate minerals. I Kinetics: Clays \& Clay Minerals 26, 434-440.

Chakravarti, S. N. and Talibudeen, O. (1961) Phosphate interaction with clay minerals: Soil Sci. 92, 232-242.

Dalal, R. C. (1975) Hydrolysis products of solution and exchangeable aluminium in acidic soils: Soil Sci. 119, 127-131.

Frink, C. R. and Sawhney, B. L. (1967) Neutralization of dilute aqueous aluminium salt solutions. Soil Sci. 103, 144148.

Low, P. F. (1955) The role of aluminium in the titration of bentonite. Soil Sci. Soc. Am. Proc. 19, 135-139.

Pyman, M. A. F., Posner, A. M., and Talibudeen, O. (1976) Hydrolysed aluminium ions on montmorillonite: Rothamsted Exp. Stn. Rep. for 1975, Part 1, 94-95.

Rich, C. I. (1970) Conductimetric and potentiometric titration of exchangeable aluminium: Soil Sci. Soc. Am. Proc. 34, 31-38.

Schwertmann, U. and Jackson, M. L. (1963) Hydrogen-aluminium clays: A third buffer range appearing in potentiometric titration: Science 139, 1052-1053.

Schwertmann, U. and Jackson, M. L. (1964) Influence of hydroxy aluminium ions on $\mathrm{pH}$ titration curves of hydroniumaluminium clays: Soil Sci. Soc. Am. Proc. 28, 179-183.
Smith, B. H. and Emerson, W. W. (1976) Exchangeable aluminium on kaolinite: Aust. J. Soil Res. 14, 43-53.

Stol, R. J., van Helden, A. K., and de Bruyn, P. L. (1976) Hydrolysis-precipitation studies of aluminium (III) solutions. 2. A kinetic study and model: $J$. Colloid Interface Sci. 57, 115-131.

Turner, R. C. (1968a) Conditions in solution during the formation of gibbsite in dilute aluminium salt solutions: I. Theoretical treatment of the effect of the formation of monoand polynuclear hydroxy-aluminium ions, precipitations and crystallization on curves representing the titration of $\mathrm{AlCl}_{3}$ with a base: Soil Sci. 106, 291-296.

Turner, R. C. (1968b) Conditions in solution during the formation of gibbsite in dilute aluminium salt solutions: II. Effect of length of time of reaction on the formation of polynuclear hydroxy-aluminium cations, the substitution of other anions for $\mathrm{OH}^{-}$in amorphous $\mathrm{Al}(\mathrm{OH})_{3}$ and the crystallization of gibbsite: Soil Sci. 106, 338-344.

Vermeulen, A. C., Geus, J. W., Stol, R. J., and de Bruyn, P. L. (1975) Hydrolysis-precipitation studies of aluminium (III) solutions: I. Titration of acidified aluminium nitrate solutions: J. Colloid Interface Sci. 51, 449-458.

de Villiers, J. M. and Jackson, M. L. (1967a) Cation exchange capacity variations with $\mathrm{pH}$ in soil clays: Soil Sci. Soc. Am. Proc. 31, 473-476.

de Villiers, J. M. and Jackson, M. L. (1967b) Aluminous chlorite origin of $\mathrm{pH}$-dependent cation exchange capacity variations: Soil Sci. Soc. Am. Proc. 31, 614-619.

Vogel, A. I. (1961) A Text-book of Quantitative Inorganic Analysis: 3rd ed., Ch. I, Longman, London.

Резюме-Ацилированные суспензии насыщенных Al каолинита, монтмориллонита, слюды, иллита, и биотита, в $10^{-3} \mathrm{M} \mathrm{NaNO}_{3}$ были последовательно потенциометрически титрованы с $0,1 \mathrm{~N} \mathrm{NaOH}$ и $0,1 \mathrm{~N}^{2} \mathrm{NO}_{3}$ в азотной атмосфере, свободной от $\mathrm{CO}_{2}$. Результирующие кривые сравнивались с кривыми для растворов $\mathrm{Al}\left(\mathrm{NO}_{3}\right)_{3}$ с такой же концентрацией $\mathrm{Al}$ как в отстоявшемся растворе и корректировались за Al в захваченном растворе с глине.

Основные титры ионов $\mathrm{Al}$, адсобированные всеми минералами, за исключением монтмориллонита, показывали два перегиба рН, разделенные буферным диапазоном. Что касается монтмориллонита, то здесь были три перегиба, подобных перегибам для Al в растворе. Первые перегибы в титре суспензий появлялись при низких значениях $\mathrm{pH}$ и были менее выражены, чем перегибы для $\mathrm{Al}$ в растворе. Они представляют титры $\mathrm{H}_{3} \mathrm{O}^{+}$, сорбированного в течение предварительной обработки. Буферное действие адсорбированных ионов $\mathrm{Al}$ также слабее по сравнению с Al в растворе.

$\mathrm{OH}^{-}$, использующийся адсорбированными ионами $\mathrm{Al}$ между первым и последним перегибами, был равен или несколько выше катионной обменной способности минералов, за исключением слюды, где он более чем в два раза превышал его катионную обменную способность, потому что образовались новые межслойиые поверхности во время предварительной кислотной обрабртки. Кривые кислотного титровання ионов Al в адсорбированном и растворенном состояниях показывали гистерезис, когда относились к кривым основного титрования. Использование двух скоростей титрования (3 и $0,3 \mathrm{pH}$ единиц/ч только незначительно воздействует на кривые титрования минералов, показывая, что наблюдавшиеся эффекты не были вызваны отсутствием равновесия с добавленными основанием или кислотой. 
Resümee-Angesäuerte Suspensionen von mit Al gesättigten Kaolinit, Montmorillonit, Glimmer, Illit, und Biotit in $10^{-3} \mathrm{M} \mathrm{NaNO}_{3}$ wurden nacheinander mit $0,1 \mathrm{~N} \mathrm{NaOH}$ und $0,1 \mathrm{~N} \mathrm{HNO}_{3}$ in einer Kohlendioxyd freien Atmosphäre potentiometrisch titriert. Die resultierenden Titrationskurven wurden mit denen für $\mathrm{Al}\left(\mathrm{NO}_{3}\right)_{3}$ Lösungen mit ähnlichen Al-Konzentrationen in der überstehenden Flüßigkeit verglichen und korrigiert für $A l$ in den eingeladenen Lösungen im Ton. Als Al-Ionen, adsorbiert auf allen Mineralien mit Ausnahme von Montmorillonit, mit Basen titriert wurden, zeigten sich zwei pH-Inflektionen, welche durch ein Pufferbereich getrennt waren. Mit Montmorillonit gab es drei pH-Inflektionen, die denen von $\mathrm{Al}_{\text {.. }}$ in Lösung gleichen. Die ersten Inflektionen in der Titrationen von Suspensionen findet bei niedrigen $\mathrm{pH}$ Werten statt und sind weniger ausgeprägt als für $\mathrm{Al}$ in Lösung. Diese repräsentieren die Titration von $\mathrm{H}_{3} \mathrm{O}^{+}$, welches während der Vorbehandlung adsorbiert wurde. Adsorbierte Al-Ionen puffern weniger als Al in Lösung. Das $\mathrm{OH}^{-}$, welches von den adsorbierten Al-Ionen zwischen den ersten und letzten Inflektionen verbraucht werden, entsprach oder war etwas höher als das CEC der Mineralien mit Ausnahme des Glimmer, für den es mehr als zweimal seines CEC war, weil neue Zwischenschichtflächen während der säurevorbehandlung geformt worden. Säuretitrationskurven von Al-Ionen im adsorbierten und Lösungszustand zeigte Hysteresis, wenn man sie auf die Alkalititrationskurven bezieht. Die Benutzung von zwei Titrationsgeschwindigkeiten ( 3 und $0,3 \mathrm{pH}$ Einheiten/h) hatten nur wenig Einfluß auf die Titrationskurven, was andeutet, daß die beobachteten Effekte nicht durch Mangel eines Gleichgewichts mit zugefügter Base oder Säure verursacht wurden.

Résumé-Des suspensions acidifiées dans $10^{-3} \mathrm{M} \mathrm{NaNO}_{3}$ de kaolinite, de montmorillonite, de mica, d'illite, et de biotite saturés d'Al ont été potentiométriquement titrées avec $0.1 \mathrm{~N} \mathrm{NaOH}$ et $0.1 \mathrm{~N} \mathrm{HNO}_{3}$ en succession, dans une atmosphère nitrogénée sans $\mathrm{CO}_{2}$. Les courbes résultantes ont été comparées à celles de solutions d' $\mathrm{Al}\left(\mathrm{NO}_{3}\right)_{3}$ de concentration Al semblable dans la solution surnageante et corrigées pour $\mathrm{Al}$ dans la solution entrainée dans l'argile. Des titrages basiques des ions Al adsorbés sur tous les minéraux sauf la montmorillonite, ont montré 2 inflexions de $\mathrm{pH}$ séparés par une région tampon. Pour la montmorillonite, il y avait 3 inflexions de $\mathrm{pH}$ semblables à celles pour l'Al en solution. Les premières inflexions dans les titrages des suspensions ont survenu à de plus bas $\mathrm{pH}$ et étaient moins prononçés que dans le cas de l'Al en solution. Celles-ci représentent le titrage de $\mathrm{H}_{3} \mathrm{O}^{+}$sorbé pendant le prétraitement. L'effet de tampon produit par les ions d'Al adsorbé est aussi moins élevé que celui d'Al en solution. $\mathrm{L}^{\prime} \mathrm{OH}^{-}$utilisé entre les premières et dernières inflexions par les ions d'Al adsorbés était égal à ou un peu plus élevé que la capacité d'échange de cations (CEC) des minéraux, sauf dans le cas du mica, où il était plus de deux fois plus élevé que son CEC parceque de nouvelles surfaces interfeuillet ont été formées pendant le prétraitement acide. Les courbes de titrage acide des ions Al dans les états adsorbés et en solution ont montré une hystérésis lorsque mis en relation avec les courbes de titrage basique. L'emploi de deux vitesses de titrage ( 3 et $0.3 \mathrm{pH}$ unités/h) n'a affecté que très peu les courbes de titrage des minéraux suggérant que les effets observés n'étaient pas causés par un manque d'équilibre dû à l'addition de base ou d'acide. 